\title{
Stage III Vaginal Cancer AJCC v8
}

National Cancer Institute

\section{Source}

National Cancer Institute. Stage III Vaginal Cancer A/CC v8. NCI Thesaurus. Code C139665.

Stage III includes: (T1-T3, N1, M0); (T3, NO, M0). T1: Tumor confined to the vagina. T2:

Tumor invading paravaginal tissues but not to pelvic sidewall. T3: Tumor extending to the pelvic sidewall and/or involving the lower third of the vagina and/or causing hydronephrosis or nonfunctioning kidney. N0: No regional lymph node metastasis. N1: Pelvic or inguinal lymph node metastasis. M0: No distant metastasis. (AJCC 8th Ed.) 